\title{
Redefining Permanent Establishment Concept of e-Commerce Cross-border Transaction: A Preliminary Study in Indonesia
}

\author{
Hendri, Ning Rahayu and Mila S. Setyowati \\ University of Indonesia, Depok, Indonesia
}

Correspondence should be addressed to: Hendri; hendri.suvaco@gmail.com

Received date: 1 August 2020; Accepted date: 29 April 2021; Published date: 31 August 2021

Academic Editor: Angela Lee

Copyright (C) 2021. Hendri, Ning Rahayu and Mila S. Setyowati. Distributed under Creative Commons Attribution 4.0 International CC-BY 4.0

\begin{abstract}
The development of e-commerce transaction has created problems in taxation policy. The tendency of tax avoidance occurs when countries place little attention to mitigate the problem. Most countries, including Indonesia, face the problem of tax avoidance practices as e-commerce practices can bypass States' territorial boundaries. This happened because most of the developing countries, such as Indonesia, are the recipient of the technological advancement in which cross border e-commerce transaction occurs. By using technology, e-commerce companies tend to do a tax avoidance by ignoring a traditional Permanent Establishment model, which inflicts a long-run financial loss for developing countries. This research focuses on the discussion of alternate Permanent Establishment models in facing cross-border e-commerce transaction, which are: Base Erosion Approach, Virtual Permanent Establishment Approach, and Refundable Withholding Approach. By highlighting the models, this research discusses advantages and challenges of each approach to enrich the discussion of cross-border transaction regulatory framework in Indonesia. The research believed that Virtual Permanent Establishment approach is the most suitable for Indonesia, as it can maintain the integrity of international taxation system in effect by redefining PE principle, albeit the challenges in convincing other countries to take part in the negotiation.
\end{abstract}

Keywords: E-commerce, Tax, Tax Avoidance, Permanent Establishment, Cross-border taxation

Cite this Article as: Hendri, Ning Rahayu and Mila S. Setyowati (2021)," Redefining Permanent Establishment Concept of e-Commerce Cross-border Transaction: A Preliminary Study in Indonesia ", Journal of Internet and e-Business Studies, Vol. 2021 (2021), Article ID 565889, DOI: 10.5171/2021.565889 


\section{Introduction}

The rapid development of e-commerce has made Indonesia a vast potential country for the business community to expand its market. Within a considerable market size in Indonesia, e-commerce is transforming into a business that can fulfill people's daily needs. In actual, e-commerce offers the same services compared to the brick-and-mortar business. However, the advancement of technology has made e-commerce move wellbeyond the traditional market. Now, the developed country is dominating the use of technology, where most of the primary players are the companies who reside outside Indonesia. Thus, this condition will do many international businesses eyeing for Indonesia's market of e-commerce (Mukarromah 2014).

According to We are social and Hootsuite (2017), Indonesia, Internet users exceed 132.7 million people with 123,3 million are the mobile Internet users in January 2017. Around 51 percent of the population are active Internet users, and 47 percent are actively using mobile Internet. It is found that 77 percent of people are accessing the Internet every day. Thus, these data confirmed that the e-commerce industry in Indonesia is backboned by the high penetrable Internet users.

By using this advantage, e-commerce companies can do many things to make people more comfortable to consume goods and services. Google, for example, can filter and compare goods and services form the various e-commerce marketplaces. So, people can search for one keyword of the desired item without breaking a sweat. Besides Google, there are other e-commerce companies in which consumers can easily navigate goods and services, such as Alibaba.com, Lazada, Amazon and many more. With e-commerce, consumers do not have to go to China to buy things there. They have to create an account in Alibaba.com to enjoy the simplicity. The case is also the same if the consumers want books that are unavailable in Indonesia. Amazon.com provides limitless opportunities to buy books from all over the world.

A tremendous e-commerce market potential in Indonesia is, indeed, causing a taxation effect in which fiscal authority needs to pay more attention. The absence of the rule of law regarding this issue has made it attractive to discuss the topic even further. Western countries, who first enjoyed Internet advancement, have done many research studies regarding e-commerce taxation in the last ten years. The US, for example, established Electronic Commerce Tax Study Group (ECTSG) in 1995. This fact showed that the US was paying much attention to how to impose e-commerce tax policy since the very beginning. Most of the developed countries, like the US, applied comprehensive tax system to the income tax of all transactions within its jurisdiction (Downer, 2016).

The tax treaty, among the country partners, is still the primary obstacle for Indonesia to uphold the right to taxing cross-border ecommerce transaction. The problem arises because the Permanent Establishment (PE) concept in the treaties required a physical appearance to run the business. In the case of e-commerce, none of the e-commerce companies even need a physical appearance to become a marketplace for all.

Moreover, the condition will create an opportunity for tax avoidance, chiefly conducted by the companies who run a cross-border transaction. Of course, if there are no other means to tackle the problem, Indonesia will lose a tax income potential. Thus, the needs to redefine the PE concept on the tax treaties become more urgent and vital on a long run.

This research aims to discuss alternate Permanent Establishment models in facing

Hendri, Ning Rahayu and Mila S. Setyowati, Journal of Internet and e-Business Studies, DOI: $10.5171 / 2021.565889$ 
cross border e-commerce transaction, which are: Base Erosion, Virtual Permanent Establishment and Refundable Withholding. The research discusses advantages and challenges of each approach to enrich the discussion of e-commerce cross border transaction regulatory framework in Indonesia. After providing an overview of the concept of e-commerce, the study examines significant elements that impact its implementation in Indonesia, including tax avoidance as a regulatory challenge, Indonesia's current e-commerce regulation and the three alternate approaches.

\section{The overview of the concept of $e$ - commerce}

Before discussing the problem, it is important to have a firm definition about ecommerce concept. Electronic Commerce (ecommerce) is a trade process which uses the Internet as a primary medium (Hellerstein et al. 2001; Van Der Bruggen 2015; Verwey 2007). In 2002, OECD introduced two definitions of e-commerce. The first definition explained the general concept of ecommerce and the second definition explained the particularity of e-commerce. These are the definitions:

"An electronic transaction is the sale or purchase of goods or services, whether between businesses, households, individuals, governments, and other public or private organizations, conducted over computer mediated networks. The goods and services are ordered over those networks, but the payment and the ultimate delivery of the good or service may be conducted on or offline." (OECD 2002)

"An Internet transaction is the sale or purchase of goods or services, whether between businesses, households, individuals, governments, and other public or private organizations, conducted over the Internet. The goods and services are ordered over those networks, but the payment and the ultimate delivery of the good or service may be conducted on or off-line." (OECD 2002)

From the definitions, OECD differentiates the two meanings by addressing transaction element. In the former description, ecommerce occurred by using electronic transaction or computer-mediated network. Then, the latest definition mentioned ecommerce as an Internet-based transaction. Though, the two definitions still stress the importance of ICT in developing e-commerce transaction.

E-commerce is known within its two types of process, which are indirect commerce and direct commerce. The indirect e-commerce is an Internet-based transaction in which traditional means of distributing goods occurs in the process, such as using courier agencies or postal services. The transactions are usually consisting of physical goods in this type of commerce. Meanwhile, the direct e-commerce means that the transaction is happening without the buyers ordering physical goods, such as software, entertainment contents, and services (Community Research and Development Information Service 1997).

In general, there are four types of ecommerce transactions. First is the businessto-business (B2B) transaction, where there are two companies at minimum conducting e-commerce transaction using the component of e-infrastructure and e-market. E-infrastructure is a B2B architect such as logistic system, supporting applications, webhosting, software and other, whereas emarket is a webpage where the transaction happens between companies (Zorayda 2003).

The second type is the business-to-consumer transaction or B2C. This type consists of a 
transaction between companies who sell goods and services and consumers through the Internet. The seller can offer any goods and services, including the direct and indirect e-commerce process. The real example of this type is amazon.com, tokopedia.com, and Rakuten.com (Zorayda 2003).

The third type is the business-to-government (B2G) transaction, where the companies offer goods and services to government entities via the Internet. Usually, the transaction can be a procedure registration, permit, advertisement, and other transaction. The last type is a consumer-to-consumer (C2C) transaction. This type permits a business between consumers in e-market, where an individual can sell goods or services and place an auction. eBay is the best example of the $\mathrm{C} 2 \mathrm{C}$ type of transaction.

\section{The existing concept of Permanent Establishment}

Traditionally, Pinto (2003) states that Permanent Establishment (PE) can be understood by two ways: (1) physical PE concept; and (2) PE agent concept. There are exceptions in the two concepts if the business status being run by the $\mathrm{PE}$ is included in the support or preparation activity stage.

In the physical PE concept, there are three PE conditions that can be considered as physical PE. First is the physical presence of the place in form of building or machinery. It would not matter if the place was bought or rented out by the business doers. As long as the place is being utilized for business activity, then it can be considered as PE (OECD 2003; Pinto 2003). The PE as mentioned at the first point is: (1) place of management; (2) branch; (3) office; (4) factory; (5) workshop; and; (6) mine, oil \& gas well, quarry site, or natural resource extraction site (OECD 2003).
Second, there is a permanent business place by time and place aspect. This means that the PE must be situated in a precise geographical area (Doernberg \& Hinnekens 1999). Such clarity does not mean that the PE must be situated at the place permanently. OECD added that for a business to run and possess a PE, there must be a connection between business place and business location. In this case, $\mathrm{PE}$ is temporal under its attachment to the business entity (Pinto 2003). The last requirement is that business activity must be run in a registered PE. Therefore, there is a human intervention dimension towards the PE. At a certain point, machine intervention (such as an automatic vending machine or other automation) does apply to the PE, but under the condition that the business entity moves surpassing beyond the scope of the machine (Pinto 2003).

PE agent concept is imposed to the representative of the business entity. To establish a PE, business entity does not have to establish its representative office. However, it can appoint an individual or an entity as an agent that represents its interests (Darussalam \& Ngantung 2017; OECD 2003; Pinto 2003).

According to Pinto (2003), exceptions in the OECD Model concept can be the main problem in the tax system of e-commerce. In the e-commerce scheme, transaction activity such as advertising and digital product sales can be included in the category as PE. Therefore, a further formulation of PE ecommerce transaction is needed.

E-commerce PE formulation became important since there are many corporations that took advantage of the gap. The concept related to e-commerce PE can be elaborated in two types: (1) concept of server as PE: According to Vink (1998), "A permanent establishment does not exist if the enterprises merely set up the equipment, which is then leased to other companies. A permanent establishment may exist,

Hendri, Ning Rahayu and Mila S. Setyowati, Journal of Internet and e-Business Studies, DOI: $10.5171 / 2021.565889$ 
however, if the enterprises not only set up the machines, but also operates and maintains them for its own account". This explains that machine operation and maintenance may also cause PE. In line with this concept, several experts also concluded that a server can be categorized as PE if the server is a physical facility that's being utilized for sales transaction and (2) concept of Virtual PE: Hinneckens as quoted from Bohorquez (2016) stated that: "The taxing nexus for electronic commerce should be "the continuous commercially significant conduit of business activity", rather than fixed place of business. The virtual PE approach applies to the jurisdictional criterion for source-based taxation of profits". This theory explains that what is essential in e-commerce activity lies in the continuity of commercial activities rather than the presence of a fixed business place. This approach can be applied on a country that adopts the source principle.

From the two concepts above, OECD has included Virtual PE concept to the BEPS recommendations that added the criteria for the formation of PE through the significant digital presence. This criterion is only intended for companies that are involved in fully dematerialized digital activities. Such activity must also be conducted in a significant manner (Darussalam \& Ngantung 2017).

Darussalam and Ngantung (2017) mentioned several examples of activities that included in the fully dematerialized digital activities category, such as: (1) main company activities are fully or partially depended on delivery of digital products or services; (2) activities within corporate chain do not involve physical entity or activity other than presence, utilization, or maintenance of server and website or other IT devices and also collection, processing, and commercialization of relevant location data; (3) contract closure activity that is exclusively conducted from long-range via telephone or Internet; (4) payment activity that can only be done via credit card or other electronic payment methods that utilize online form or platform that is linked or integrated with website; (5) website is the only way to get into business relations with companies. There's no physical business office that runs the main corporate activities other than office that is located at the parent company or in the country where the company conducts different business activities; (6) the whole or most part of business profit generated from delivery of digital product or services; and (7) the legal or physical presence of the seller is ignored by customers or it does not affect customers' preference.

The utilization of digital products or services does not need physical presence or involvement of physical product other than computers, mobile applications or other IT devices. Furthermore, OECD as quoted by Darussalam and Ngantung (2017) mentioned several examples of the condition of digital presence that are considered as significant: (1) most of the contracts for digital products or service procurements are signed by the company and its customer remotely; (2) digital products or services of company are used or consumed significantly in a certain country; and (3) there's a big amount of payments from clients of a certain country to the company in respect with the contract's obligations over digital product or service procurements.

Branches of the company provide supporting functions, such as marketing and consultation, that are targeted towards clients in a certain country and those who are closely related to primary company business.

\section{Double taxation}

Double taxation happens when there is more than one country that imposes taxation rights on a transnational transaction. According to Darussalam et al (2010), 
juridically there are two means of taxation: (1) Domicile Country imposes tax towards tax subject from the income that the source country received and (2) Source Country imposes tax towards income from Domicile Country's Tax Subject that came from its own country.

According to the domestic taxation system, taxation rights claim can be seen from two factors, those are: (1) based on personal connecting factor that evokes taxation rights claim towards income that came either from the internal territory of a country or from external (worldwide income or what is known as universality principle) and (2) based on objective connecting factor that evokes taxation rights claim that is limited only to revenue from a particular country (limited tax liability or what is known as territoriality principle) (Darussalam et al. 2017).

In the implementation, often conflict arises when considering taxation rights claim. According to Surahmat (2005), there are three conflicts in imposing international double taxation, those are: (1) the conflict between domicile principle and source principle: this conflict occurs when there's a transnational transaction that involves two countries that adopt domicile principle and source principle. All income received from the whole globe will be imposed a tax by countries that adhere to the domicile principle (worldwide income principle), whereas country with source principle will impose a tax only on income that originated from its country and (2) conflict based on differences in the definition of "resident": this type of conflict occurs because of differences in understanding "resident," where the taxpayer, either individual or corporation, may be considered as a resident of two countries. This situation allows the possibility that taxpayer will be imposed tax twice. This conflict emerges especially in a country that considered citizenship principle as secondary criteria in determining whether someone is its citizen. This conflict usually occurs on the individual taxpayer and is known by the term dual residence.

\section{The residence-based and source-based taxation controversy in e-commerce cross-border transaction}

The rapid development of communication and technology has created new challenges for the decision makers to construct an international taxation system that can be in line with the domestic taxation policy. To create a harmony and a consistent international tax system, the challenges are to choose between the principle of sourcebased and residence-based taxation (Cockfield et al. 2013).

The developed country, such as the United States (US), tends to apply the residencebased system as it will be more beneficial for them. There are two reasons why they choose that system. First, the principle guarantees the government of developed countries, as an exporter of ICT, to gain the most significant yield from the investment made by their companies. Second, the residence-based taxation is easy to implement administratively (administrative efficiency) because it does not need detail information from each e-commerce transaction.

The developing countries, as a consumer of digital goods, tend to adopt the source-based principle because of two reasons. First, the system prevents the loss of potential taxes. This issue is vital for the governments of developing countries as they usually have smaller tax base as compared to developed countries. To put it differently, developed countries aim to avoid the so-called Base Erosion and Profit Shifting (BEPS). Second the choice of this principle cannot be separated from the principle of inter-nation equity, where every country deserves to gain equal tax revenue from every cross-border transaction.

Hendri, Ning Rahayu and Mila S. Setyowati, Journal of Internet and e-Business Studies, DOI: $10.5171 / 2021.565889$ 
To overcome the controversy, there is a need to build a taxation system that can accommodate both developed and developing countries aspiration. Nevertheless, the harmonization of the principles in taxation system must also be consistent with the norms and logical frameworks of the current international taxation system, such as OECD's model of PE. The PE concept in international taxation system is based on the interplay between the taxpayer and tax authority both geographically and physically. The geographical and physical attachment set and limit the authority of tax agency only upon the taxpayer residing physically within its jurisdiction (OECD 2003). In other word, tax agency does not have an authority to collect tax from a taxpayer residing outside its jurisdiction.

Although the authority of tax agency is limited to the concept of PE, the concept itself is not a rigid and unchangeable concept. Cockfield et al (2013) provide examples of the flexibility of PE concepts in real-world applications. For example, the discussions among OECD tax experts decide that individuals or organizations not within the jurisdiction of tax authorities for more than 183 days cannot be categorized as PE. Another example, an organization or an individual may be categorized as a PE if the organization or institution has a representative or an agent to make a business contract representing the individual or organization. The organization must consistently use this authority, even if the organization or individual is not physically located in within the jurisdiction of the tax authority on which the agent is situated (OECD, 2003).

In the context of e-commerce, the flexibility of the concept of PE is essential to define the range of authority of the tax authorities. Technological developments in information technology and telecommunications have enabled individuals or companies to perform virtually cross-border business transactions without the need to be physically present. As a result, businesspeople can avoid tax avoidance and harm the source income country.

\section{Tax avoidance in e-commerce transaction}

As explained, the development of ecommerce has become a challenge for tax authorities and tax principles that are based on PE principles. In the traditional crossborder trade situation (Cockfield et al., 2013), company A that came from country A will establish a branch in which it is a PE in country B to conduct business transaction with consumers at the location (in its variety branch from company A can be substituted with individual or company that acts as agent with legal authority to conduct legitimate business transaction for company A). With the presence of such PE, tax authorities in country B are authorized to collect taxes on income from company A from its business transactions in country $\mathrm{B}$.

As explained, the development of ecommerce has become a challenge for tax authorities and tax principles that are based on PE principles. In the traditional crossborder trade situation (see figure 1), company A that came from country A will establish a branch in which it is a PE in country $\mathrm{B}$ to conduct business transaction with consumers at the location (in its variety branch from company A can be substituted with individual or company that acts as agent with legal authority to conduct legitimate business transaction for company A). With the presence of such PE, tax authorities in country B are authorized to collect taxes on income from company A from its business transactions in country $\mathrm{B}$.

However, the advancement of information and telecommunication technology, especially Internet technology, has given the possibility for company A to conduct a transaction with consumers in country B by 
virtual or without being physically present in the jurisdiction of country B. Two steps can do this virtual presence. The first step is by utilizing company A's website whose server is in country A. With such virtual presence, company A does not have to establish a PE in country B, and it can avoid taxes in country B in a legal manner (tax avoidance).

To handle with this, country B may issue a regulation that requires company $A$ to build a server in country B, which is what is happening in the negotiations between the Government of the Republic of Indonesia with Google in the last five years. Google entered Indonesia without having any PE established, forcing them to face Indonesia Tax Authority for tax negotiation (Fauzi, 2017). As reported by Tempo.co (Sawitri, 2017), Google managed to get 20.9 billion IDR and paid 5.2 billion IDR to Indonesia Tax Authority. However, the authority claimed that the number did not represent the real tax value. Since 2015, Google has tax arrears up to 5 trillion IDR based on the Indonesia Tax Authority's calculation.

Although the virtual presence of company A in country B through the website can be overcome with regulation or face-to-face negotiation between the government of country B with company A to make sure the physical presence of company A in country B in the form of website server exists in company A, there are two weaknesses in this solution model. First, direct negotiations with related companies are lex specialist, and regarding administrative cost, this way is not efficient to be implemented.

Second, several non-resident companies are still practicing tax avoidance using the service of the third party, which is the Internet Service Provider/ISP company. ISP is other parties can access a company that rents digital data center services to website owners for the website through Internet network ((Cockfield et al., 2013). As a company that provides digital data center services for company A, ISP undoubtedly possesses legal business relation. The legality of such business transaction is not necessarily considered as a basis to determine ISP as an agent with PE status for company A. This can be clarified by doing analysis towards PE's status over a server belonging to ISP.

In providing Internet hosting service to company A, ISP can place its server in Country A as a resident country of both companies or place the server in Country B as a source income country. If the ISP's servers are in Country A, the ISP may evade taxes - as described in the case of Line 1- by altering its presence in Country B from a physical presence to a virtual presence. The government of Country B can still overcome this virtual presence by implementing regulations that require ISPs to place their servers in Country B. Server placement in Country B will change the ISP's virtual status to PE, so that the tax authorities in Country B are authorized to withhold tax on ISP earnings obtained from transactions in Country B.

The tax authority of the ISP cannot be used to withdraw taxes on Company A's earnings from e-commerce transactions in Country B since ISPs are not legal entities to conduct business transactions for Company A. By utilizing this gap, Company A can still do tax avoidance through ISP web hosting services.

\section{Indonesia's e-commerce regulation}

Indonesia is placing its E-commerce regulation through Indonesia Tax Authority (DJP) Circular Letter Number 62/PJ/2013 (SE-62). On SE-62, E-commerce is divided into four categories, which are: online marketplace, online retail, classified ads, and daily deals. Regarding the e-commerce taxation, SE-62 regulates both individuals and other thresholds, who are doing ecommerce transaction, to pay any e- 
commerce transaction for goods and services (Mukarromah 2014).

However, SE-62 does not regulate cross border taxation issues for e-commerce transactions, such as online booking, app stores, cloud computing, participative networked platforms, high-speed trading, or event car rental and hotel booking who execute business outside Indonesia. It is, indeed, that the cross-border e-commerce taxation must be clearly defined to create taxation equality aspect.

Besides SE-62, the Indonesian government has recently established Presidential Decree Number 74/2017 (PP 74/2017) on Ecommerce roadmap. There are eight aspects in that decree. First, it regulates the six aspects of e-commerce funding. Second, taxation which includes elements of tax reduction for local investors at the start-up level, simplification of tax permits for startups that have a turnover of $\mathrm{Rp} 4.8$ billion/year, and equality of treatment of both foreign and domestic entrepreneurs. The third is the education and the human resources aspects, which related to public awareness in introducing e-commerce. Fourth is the e-commerce consumer protection aspect. The fifth is the national logistic system that supports the e-commerce transaction model. Sixth is the readiness of communication infrastructure. Seventh is cybersecurity aspect in transactions. The last is the establishment of organizing management of Indonesia's e-commerce roadmap.

Nevertheless, PP 74/2017 is only regulating local e-commerce roadmap, focusing more on the development of e-commerce local business environment. Then, how about the e-commerce cross border transaction, if the decree put the matter in absence? Regarding that, the tax uses the concept of PE, which is regulated in Income tax law No. 36 of 2008 article 2 paragraph 5 . The article said that:
"A permanent establishment is a form of business used by an individual who does not reside in Indonesia, an individual who is in Indonesia no more than 183 (one hundred eighty-three) days in a period of 12 (twelve) months, and an entity that is not established and no position in Indonesia to run a business or carry out activities in Indonesia..."

The above rules are in line with the Tax Treaty agreement regulation, where Article 5 stated that "For this Convention, the term "permanent establishment" means a fixed place of business through which the business of an enterprise is wholly or partly carried on." According to Rachmanto (2000), fixed place contains three conditions: (1) there is a business place in the form of infrastructure, as mentioned in Article 5 paragraph 2, namely: place of management of companies, branches, offices, factories, workshops and mines, oil or gas wells, excavations or other places to extract natural resources; (2) the place of business must be permanent, i.e., must be in a fixed place; and (3) the company's business activities are carried out through the fixed place.

Referring to the abovementioned regulation, Indonesia is placing the concept of PE to regulate taxation as attributing to the tax treaty agreement. Thus, the problem of ecommerce cross border transaction is more than pertinent to be discussed further, especially when Indonesia does not yet mitigate the issue by constructing a proper plan and regulation.

\section{Redefining the PE concept}

To cope with this problem, it needs an adjustment on the existing PE principles so that it can accommodate the technological development of the Internet that is becoming rapid. Pinto (2003) suggested three approaches to update the PE principles, which are: Base erosion approach, Virtual 
permanent establishment approach, and Refundable withholding approach.

Base erosion approach, or what is known as single rate withholding approach, was first initiated by Richard Doernberg. With this approach, Doernberg tried to accommodate the anxieties of countries that imported ecommerce transaction model, such as India and Indonesia, without having to abandon PE principles that already grip the international taxation. Other than accommodating these anxieties, Doernberg also tried to minimalize the effect of double taxation as excess from the implementation of the source-based taxation system (Doernberg \& Hinnekens 1999).

In this approach, a country where the business transaction takes place is authorized to collect single rate withholding tax for every income gained from transactions that are potential to grind tax basis of the country. To prevent double taxation from happening, Doernberg also suggested that the single rate taxes imposed can be credited or deducted from the income tax amount that has been paid to the origin country of the non-resident company. However, the implementation of this approach is not smooth because it requires an agreement and cooperation between source and residence countries, primarily related to single rate that is imposed and base erosion criteria.

Unlike base erosion approach that tries to maintain the integrity of PE principles by imposing single rate withholding tax in regard with an agreement between source and residence countries, virtual permanent establishment approach as initiated by Luc Hinnekens copes with challenges in taxation in e-commerce context by redefining the PE principles. According to Hinnekens, PE principles that currently exist are heavily relying on permanent physical presence concept in the source country (fixed place of business). This is, of course, contradictory to the existing reality of technology development, in which individual and company presence may happen in a virtual dimension. To overcome this challenge, Hinnekens suggested the relaxation of PE principles into a permanent virtual establishment (Hinnekens 1998).

This kind of approach has two main elements. First is the relaxation of $\mathrm{PE}$ principles by erasing fixed place of a business requirement to accommodate the virtual characteristic of e-commerce. Second is creating clear limitations between core business activities and ancillary business activities. Based on these two elements, source country will collect taxes from core business activities owned by companies with virtual PE status (Hinnekens 1998).

Although virtual permanent establishment approach may seem radical, according to Skaar (1991), this approach is much better than the other approaches that are more radical because they try to erase $\mathrm{PE}$ principles to enforce source-based taxation system. Such example is the benefit theory by Klaus Vogel. This theory stated that source country might collect taxes from a nonresident company regardless of whether the company has already established PE in the country because the company does not only benefit from the market base but also makes use of state-owned public facilities directly or indirectly (Pinto 2003; Vogel 1988).

The last, a refundable withholding approach is an approach that is global because it requires multilateral agreement and cooperation. In this approach, source countries are authorized to collect withholding tax over each business transaction obtained from e-commerce activities.

Different from base erosion approach as proposed by Professor Doernberg, the tariff rate charged in this approach is determined through multilateral agreement, so the rate 
that is charged will be retroactive (uniform) in the whole world. Other than that, the tax that is imposed is refundable if the total value of gross sales taxable is below the de minimis threshold (Pinto 2003).

\section{Advantages and challenges of each approach}

The rapid development of e-commerce is a challenge for the current international taxation system. To overcome this, experts in the field of international taxation proposed three approaches, which are base erosion, permanent virtual establishment, and refundable withholding. However, each of the approaches has its superiorities and challenges (Pinto, 2003). For example, refundable withholding offers a global standard to address e-commerce challenge nowadays, but this approach needs multilateral agreement and coordination through international organizations to be appropriately implemented. In a narrower context, which is in Indonesian national fiscal sovereignty context, this approach is not proper.

Regarding challenges, base erosion and virtual permanent establishment approach still require international agreement and cooperation, either in bilateral or multilateral limited scales, such as between ASEAN or European Union countries. There are apparent differences between these approaches from superiority side. Compared to the base erosion approach, the virtual permanent establishment approach gives a solution which is more continuous and fundamental by utilizing flexibility from the PE principles per se. As explained by Cockfield et al (2013), the main strength of the international taxation system lies on the flexibility of PE system application that adapts to technology and era development.

\section{Conclusion}

Tax avoidance practices that occur in crossborder transactions of e-commerce arise in the absence of a policy that regulates these cross-border transactions explicitly. Existing rules are still traditional where the concept of PE in tax treaty is defined as a place of physical position to run business activities. In other words, physical presence is still a reference for tax authorities in Indonesia.

This concept of physical presence makes the tax authorities tend to see the subject than the object. Nevertheless, with the current technological advances, physical presence is no longer needed so that business actors who become subjects in the transaction become painful to tax.

Indonesian tax authorities must make a breakthrough by redefining the concept of PE in the tax treaty. The difficulty is how to equate perception with the state treaty partner. Not all countries that have Tax Treaty agreements with Indonesia share the same views and concepts of thought related to the concept of PE in the Tax Treaty. The political and economic considerations of each country's treaty partner may influence the negotiation result of the change of $\mathrm{PE}$ concept.

The redefining PE concept for e-commerce cross border transaction is not an easy task for the Indonesia government, considering hundreds of tax treaties have been made between Indonesia and other countries. This preliminary study at the minimum can suggest two steps that can be done by the government:

1. Regarding the amendment of SE-62 Article 5 on PE concept, the government must renegotiate the tax treaties to mitigate the dynamic of technological advancement. Based on previous discussion, this research suggests virtual permanent 
establishment, where the concept should be the common concern of all countries as it transforms the overall mindset on PE. The re-negotiation process may be facing a huge obstacle as many corporations try to take an advantage from this loophole. The same loophole that will create a potential revenue loss for the DJP. Hence, the DJP must strategically construct an international campaign to uphold tax morality among the tax payers.

2. Concerning domestic PE concept based on Law No. 36 Article 2 paragraph 5, the government must be courageous to redefine the $\mathrm{PE}$ concept. The government needs to pay attention to the dynamic of technological advancement so that they can anticipate the future fiscal problems.

Future study is needed to both clarify on the suggestions and to enrich the future discussion on the topic. The research will explore stakeholders' mindset of the challenges and opportunities to redefine the PE concept in the case of e-commerce cross border transaction.

\section{Acknowledgment}

Include any acknowledgement right before the references section (if applicable)

\section{References}

- Bohoquez, Angela Carolina Vaca. (2016), Virtual Permanent Establishment: an approach to the Taxation of Electronic Commerce Transactions

- Cockfield, A., Hellerstein, W., Millar, R., \& Waerzeggers, C. (2013) Taxing global digital commerce, Wolters Kluwer Law \& Business, Alphen aan den Rijn.

- Community Research and Development Information Service, (1997). "A
European Initiative in Electronic Commerce" Community Research and Development Information Service. [Online], [Retrieved November 22, 2020].

$\mathrm{ftp}: / / \mathrm{ftp}$. cordis.europa.eu/pub/esprit/d ocs/ecomcom.pdf

- Darussalam, Hutagaol, J., \& Septriadi, D. (2010) Konsep dan Aplikasi Perpajakan Internasional, Danny Darussalam Tax Center, Jakarta.

- Darussalam, \& Ngantung, Y. W. (2017), Bentuk Usaha Tetap, Perjanjian Penghindaran Pajak Berganda: Panduan, Interpretasi, dan Aplikasi, Darussalam \& D. Septriadi (eds), Danny Darussalam Tax Center, Jakarta.

- Downer, P. (2016) 'Taxation of Electronic Commerce (e-comm): Examination of Canadian Government Tax Policies and Directives Application of Adam Smith's Canons of Taxation,' Journal of Financial Management \& Analysis, 29(1), 1-14.

- Fauzi, Y., (2017). "Setelah Google, Ditjen Pajak Kejar Pajak Badan Usaha Lainnya" CNN Indonesia. [Online], [Retrieved November 20, 2020]. https://www.cnnindonesia.com/ekono $\mathrm{mi} / 20170614101210-78-$ 221623/setelah-google-ditjen-pajakkejar-pajak-badan-usaha-lainnya/

- Hellerstein, W., Doernberg, R., Hinnekens, L., \& Li, J. (2001) Electronic Commerce and Multi-Jurisdictional Taxation, Springer Netherlands, The Hague.

- Hinnekens, L. (1998). h. 192. Looking for an Appropriate Jurisdictional Framework for Source-State Taxation of International Electronic Commerce in the Twenty-First Century. Intertax Volume 26, Issue 6/7.

- Mukarromah, A., (2014). "Pajak ECommerce Antara Hambatan dan Tantangan" Inside Tax: Media Tren Perpajakan. [Online], [Retrieved November 19, 2020]. https://ddtc.co.id/uploads/pdf/InsideTa $\mathrm{x}$-25th-Edition.pdf 
- OECD, (2002). "Measuring the Information Economy" Organisation for Economic Co-operation and Development. [Online], [Retrieved November 11, 2020].

http://www.oecd.org/dataoecd/16/14/ 1835738.pdf

- OECD, (2003). "Articles of The Model Convention with Respect to Taxes on Income and on Capital" Organisation for Economic Co-operation and Development. [Online], [Retrieved November 19, 2020].

http://www.oecd.org/tax/treaties/1914 467.pdf

- Pinto, D. (2003) E-commerce and Source-based Income Taxation, IBFD Publications, Amsterdam.

- Sawitri, A.A., (2017). "Pajak Google Dibahas di Tingkat Menteri" Tempo.co. [Online], [Retrieved November 14, 2020].

https://bisnis.tempo.co/read/848780/p ajak-google-dibahas-di-tingkat-menteri

- Skaar, A. A. (1991) Permanent Establishment: erosion of a tax treaty principle, Wolters Kluwer Law \& Business, Deventer.

- Surahmat, R. (2000) Persetujuan Penghindaran Pajak Berganda: sebuah pengantar, Gramedia Pustaka Utama, Jakarta.

- Van Der Bruggen, E. (2015) 'Electronic Commerce and International Taxation: Questions About Applying Tax Law in
Cyberspace,' $A B A C$ Journal, 20, 2 (MayAugust 2000),15-29

- Verwey, P. M., (2007). "The principles of source and residence taxation of electronic commerce transactions in South Africa" North-West University. [Online], [Retrieved November 12, 2020].

https://repository.nwu.ac.za/bitstream/ handle/10394/2125/verwey_phillipmar tin\%281\%29.pdf?sequence=1\&isAllowe $\mathrm{d}=\mathrm{y}$

- Vink, Martin. (1998). Fiscal Actualiten Caught In The Web : The Tax and Legal Implications of Electronic Commerce. Washinton : Price Waterhouse.

- Vogel, K. (1988). Worldwide vs. Source Taxation of Income - A Review and ReEvaluation of Arguments. Intertax Volume 16, Issue 8/9.

- We are social \& Hootsuite, (2017). "Digital in 2017: Southeast Asia". [Online], [Retrieved November 20, 2020].

https://www.slideshare.net/wearesocial sg/digital-in-2017-southeast-asia

- Zorayda, R. A. (2003) E-commerce and ebusiness, UNDP-APDIP, Kuala Lumpur. 